\title{
Coherence of Cadastral Data in Land Management-A Case Study of Rural Areas in Poland
}

\author{
Katarzyna Kocur-Bera *(D) and Hubert Frąszczak \\ Faculty of Geoengineering, University of Warmia and Mazury in Olsztyn, 10-719 Olsztyn, Poland; \\ hubert.fraszczak@student.uwm.edu.pl \\ * Correspondence: katarzyna.kocur@uwm.edu.pl
}

Citation: Kocur-Bera, K.; Frąszczak, H. Coherence of Cadastral Data in Land Management-A Case Study of Rural Areas in Poland. Land 2021, 10, 399. https://doi.org/10.3390/ land10040399

Academic Editor: Fabrizio Battisti

Received: 8 March 2021

Accepted: 9 April 2021

Published: 10 April 2021

Publisher's Note: MDPI stays neutral with regard to jurisdictional claims in published maps and institutional affiliations.

Copyright: (c) 2021 by the authors. Licensee MDPI, Basel, Switzerland. This article is an open access article distributed under the terms and conditions of the Creative Commons Attribution (CC BY) license (https:// creativecommons.org/licenses/by/ $4.0 /)$.

\begin{abstract}
The cadaster functions laid down in the law should guarantee the safety of one's rights. The reliability of the data gathered in the cadaster affects decisions concerning specific real estate or taken within the sphere of economic management. The legislation often requires the use of cadastral data, which makes it necessary to keep it up-to-date and coherent with the situation in the field. The effects of a lack of coherence may impact public finances and land management. Maintaining high-quality cadastral data is time-consuming and expensive. This study analysed the data coherence between the state in the field and cadastral documents. The analysis was based mainly on the information about the area of a plot and land use. The coherence index showed that the differences between registers and the state in the field range from $30 \%$ to $80 \%$. This can be changed by comprehensive data modernisation, which can be facilitated using modern technology. Given the diverse use of cadastral data and the global trends in cadaster development and implementation of the third dimension, the currency and reliability of cadastral data become particularly important.
\end{abstract}

Keywords: cadastral data; data coherence; data modernisation; land use

\section{Introduction}

The importance of current information in the cadastral systems has been emphasised in the international literature many times. These issues attract attention because cadastral data are used in many economic activities, e.g., spatial planning, establishing tax and charge obligation, describing real estate in perpetual registers, public statistics, real estate management, securing the rights of individual owners, etc. [1-3]. The coherence between the state of space at the plot level in public documents and the actual situation in the field is essential for an increase in consumer confidence and trust and affects the decision quality [1-3]. The technical reliability of cadastral data is also a condition of the legal security of boundaries [4-7]. Effective data verification and regular updating are essential in land management [6-8], although it is difficult given the amount of accumulated data [4,9-12]. Cadastral data quality has been studied extensively [10-18] and it covers a wide range of topics. Data necessary to update cadastral data are increasingly often acquired using cuttingedge technologies [13,15-20], including unmanned aerial vehicles (UAV). The issue of data transformation from $2 \mathrm{D}$ to 3D has been widely dealt with [21-25]. The third dimension provided in cadastral registers is of particular importance to developers, authorities issuing building permits and entities that perform spatial management. However, building a 3D cadaster should be based on reliable horizontal data (2D), reflecting the actual situation in the field. Cadastral data are intended to ensure (a) a legal order on the land, as far as it is necessary to establish the scope of rights, (b) a sense of security arising from the entries disclosed in the register and the possibility of asserting one's rights in administrative or court proceedings, and to guarantee, in an appropriate scope, (c) legal certainty, both in its formal and economic aspects. The latter manifests itself in the real estate tax base, which depends on the method of land use, as the authorities establishing its amount cannot take any other base than that provided in the register. The term 'land use' has a variety 
of meanings, from the nature of the vegetation that grows upon the land to the human activities that relate to the land and are carried out upon its surface [26,27]. Several types of land use exist in Poland (arable land, forests, built-up and urban areas, ecological areas, underwater land and other lands), in which individual land use types can be identified. Numerical descriptions of land use zone outlines and their marking are one of the types of cadastral data concerning land [27] and provide a base for the calculation of the real estate tax [28-31]. There are various approaches and techniques used around the world in tax base calculation [7]. Therefore, individual and mass valuation can be identified. The cadastral value of land is used for tax calculation in Belarus, Estonia, Greece and Spain. The cadastral value in Spain is linked with the market values established based on market analyses [32]. The land tax in Belarus is calculated by multiplying the plot area by the land tax rate (fixed, independent of the plot value) [33]. The real estate tax collection in Denmark and Bulgaria is based on cadastral information. The real estate tax revenue in communes in Poland is determined by legal acts that classify the types of real estate $[28-31,34,35]$ and the tax rates established for each type of land use by individual local government units. The real estate tax revenue accounts for part of the commune budget. Although an analysis of cadastral data has been dealt with in many pieces of scientific research in recent years [13-20], more studies are needed as they have a direct and indirect impact on socio-economic processes and methods of land use, etc. $[8,34,35]$. The coherence index calculated for each village under study in an innovative and synthetic manner reveals the level of incoherence of the cadastral data with the situation in the field. The studies conducted so far were based on an analysis of a section of reality (a sample). The assessment presented in this analysis applies to whole villages (precincts), which shows the real quality level of cadastral data.

This study aimed to analyse cadastral data concerning coherence between the document data (cadastral data) and the state in the field. The differences concerned the plot area, boundaries of land use methods and their types. The case study covered over 4000 plots in 14 villages in the Łódzkie Voivodship (Poland). For most of the plots, there was more than one method of use despite their small size. The discussion focused on the importance of cadastral data coherence.

The article is organised in the following manner: The introduction is followed by a description of the administrative procedure of cadastral data modernisation. It differs from the updating process mainly in terms of the legal procedure and the scale of the enterprise. This part is followed by the methodology description, analysis and discussion of results and conclusions.

\section{Background}

The legal procedure in Poland provides for three types of updating of register data: ongoing updating (a), modernisation (b) and periodical verification (c) of cadastral data. Updating the data on an ongoing basis (a) involves introducing data changes reported by real estate owners within 30 days $[28,36]$. The owners do not need to report changes that arise from normative acts, valid court decisions, etc. When data necessary to update the cadastral database cannot be obtained, the starost (the body responsible for cadastral data at the district level), can, by means of an administrative decision, impose an obligation to prepare the necessary documentation to be used to carry out the updating process. When the real estate owner evades the obligation, the data update is done by proxy with the costs being charged to the owner [28,37].

Modernisation of the land and building register (b) is a package of technical, organisational and administrative measures taken by the starost (the body responsible for cadastral data). Its aim is to supplement the cadastral database and to create a full range of register data sets and their modification. It is carried out strictly in accordance with the legally established diagram (see Figure 1). A modernisation plan is prepared, which is made public together with the information on starting the geodesic work. After it is completed, all of the parties concerned can report their comments on the project. A decision to accept or reject the comments is taken within 15 business days. It is then communicated to the persons 
concerned and the data become up-to-date cadastral data. Each real estate owner can raise objections concerning the data within 30 business days of the publication of information on accepting the data after modernisation as being up to date in the voivodeship official journal. The starost settles the dispute by issuing a decision. Geodesic field and photogrammetric measurements are the basic methods of cadastral data modernisation. It is required that the photogrammetric measurements, based on images acquired by large-format or aerial digital cameras, should be highly accurate.

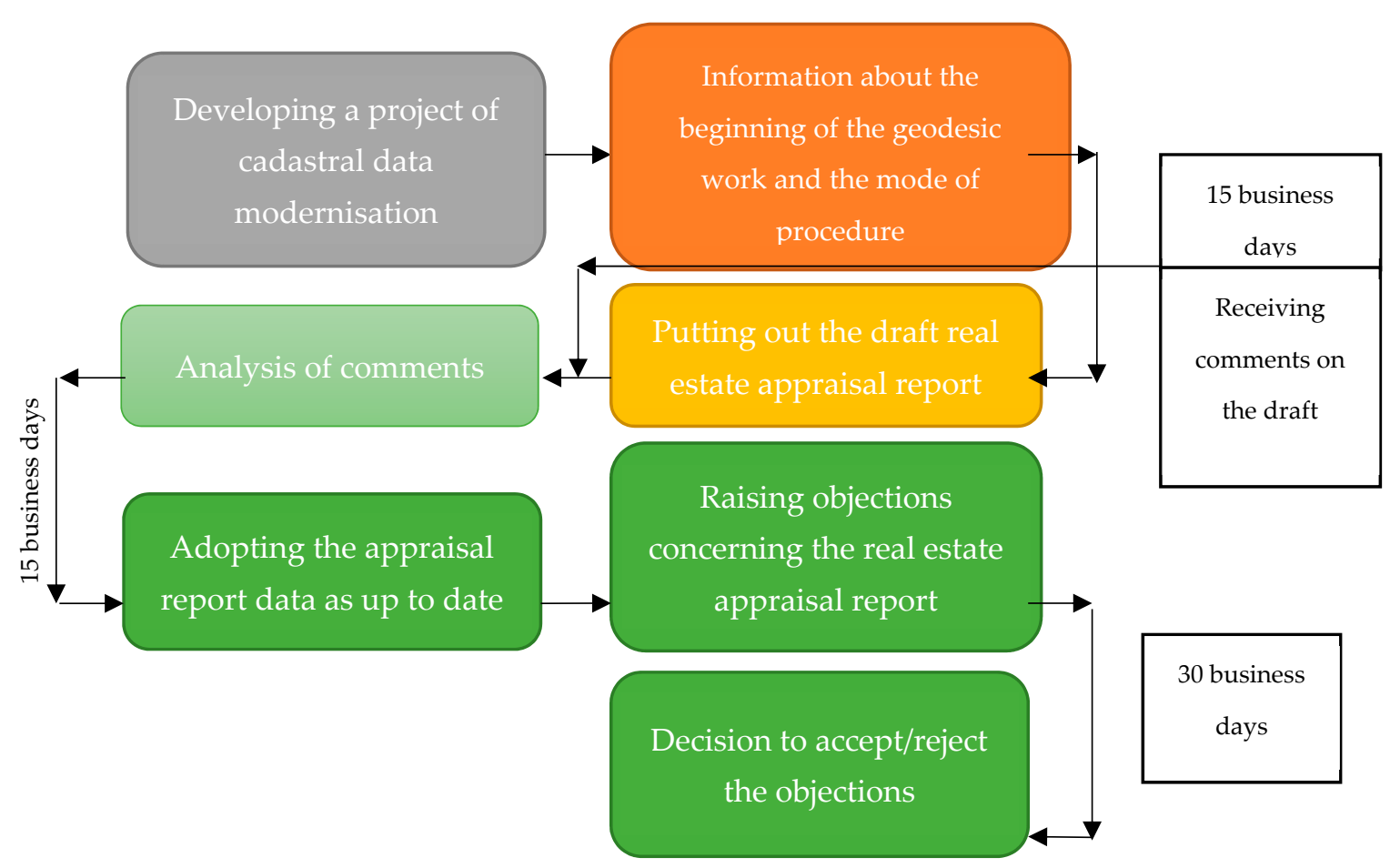

Figure 1. Stages of an administrative procedure of cadastral data modernisation.

Periodical data verification (c) involves an examination of data consistency with the source documents on which an entry in the database is based and the consistency of the cadastral map with the situation in the field. The data consistency should be confirmed at least once every 10 years in each precinct (a division unit for the cadastral purposes) and it should cover at least $10 \%$ of source documents, on which the changes are based [28]. The consistency of a cadastral map with the actual state is checked at least once every 15 years and it covers the whole precinct (village). If considerable irregularities are revealed by the verification, the starost may order all data within the precinct (village) to be checked.

Cadastral data in Poland consist of a geodesic-legal part and a descriptive-cartographic part. The geodesic-legal part is a body of legal and technical evidence, which justifies entries in databases (e.g., a transcript of a notarised deed, a list of land changes). The descriptive-cartographic part is divided into two parts. The first part-spatial—covers the cadastral map, and the other part-descriptive-covers registers and files. Each object in the register is identified by an identifier called the register unit number. Files are assigned to a building/establishment as part of the building or establishment register unit [28,37].

The scope of tasks performed during the data modernisation process usually concerns the descriptive-cartographic part, but it also includes an analysis of a geodesic-legal part. A detailed scope of tasks is presented in Figure 2.

Each task related to cadastral data modernisation implies a certain range of actions. These mainly include an analysis of the acquired materials, a field inspection, which involves both a comparison of the document state with the state in the field and direct contact with the owners (holders) of the real estate (see Figure 2). Measurements of changes and control measurements are performed. Making calculations and changes in the descriptive- 
cartographic part is an integral part of cadastral data modernisation. Lists of land changes are also made. Documentation with changes resulting from the modernisation is put out for public viewing. Real estate owners are informed about it and they can make comments about the changes (see Figure 1), which are analysed and explained each time. In the last stage, an announcement of the starost (the body responsible for cadastral data) is published, stating that new cadastral data are up to date. From that moment on, all documents issued by the body maintaining cadastral data are based on the modernised data.

Analysis of source materials.

Field inspection and a direct interview with real estate owners.

Field measurements.

Setting up a register for land, buildings and establishments if such a register does not exist for the given area.

A control field measurement of buildings (when the field inspection reveals that the plot border

was crossed) and of land (when the field inspection and a review with owners revealed changes).

Calculating the coordinates of the plot border bends (the objects were not in the register or their position changed relative to the previous data) and of the area of the updated land use areas.

\begin{tabular}{l}
\hline $\begin{array}{l}\text { Modification of existing data in the descriptive part of the register (concerning the owners and } \\
\text { other elements of the descriptive part of the register). }\end{array}$ \\
$\begin{array}{l}\text { Modification of the cartographic part with respect to the range and type of the built-up area, } \\
\text { types of land use. }\end{array}$ \\
\hline Preparing a list of land changes. \\
\hline
\end{tabular}

Figure 2. The detailed scope of technical measures which should be implemented during the cadastral data modernisation process. Source: own study.

\section{Materials and Methods}

\subsection{Research Area}

The area covered by the analysis is situated in the Łódzkie Voivodship, in the middle of Poland, in the geographical centre of Europe. The analysis was performed for 14 precincts (villages) situated in the commune of Wolbórz, Łódzkie Voivodship, Poland (Figure 3). The commune of Wolbórz has an area of $151.70 \mathrm{~km}^{2}$, with agricultural land accounting for $62 \%$ and forest for $28 \%$ of it. It has a population of 7767 people (2018) [38]. The commune has two nature reserves: Czarny Ług and Dęby in Meszcze and, partly, the nature reserve in Lubiaszów. The commune of Wolbórz is divided into 34 precincts (villages). The following were analysed: Adamów (A), Apolonka (B), PRG Bogusławice (C), Bronisławów (D), Brudaki (E), Dobra Golesze (F), Golesze (G), Janów (H), Kaleń (I), Komorniki (J), Krzykowice (K), Kuznocin (L), Kolonia Żywocin (M), Wolbórz (N). The coordinates of the central part of the commune are $51^{\circ} 30^{\prime} 03^{\prime \prime} \mathrm{N} 19^{\circ} 49^{\prime} 56^{\prime \prime} \mathrm{E}$. 


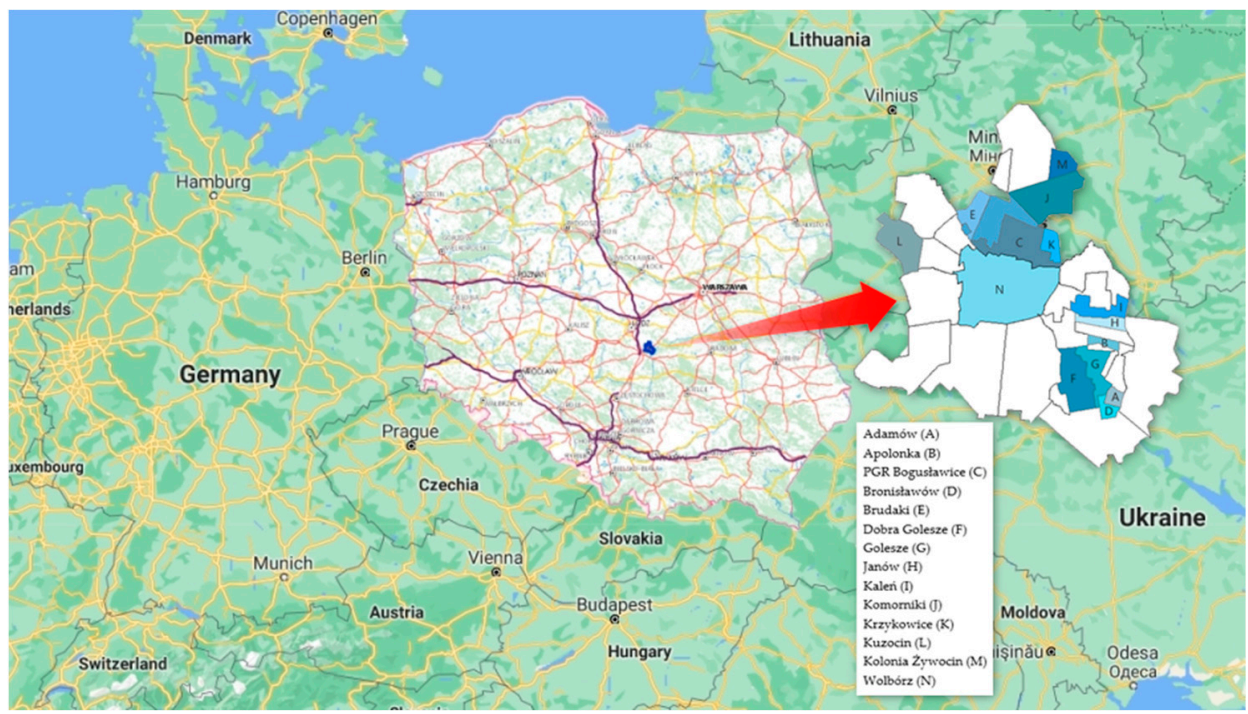

Figure 3. Study area. Source: own study [39-41].

\subsection{Methods}

The coherence index between the data in the field and those in the cadastral database was determined based on the average absolute change of a plot size in a village (X1), the index of the number of plots with a size change in an object (X2), the number of land use methods with a size change $(X 3)$ and the average absolute change of area size in an object (X4). Determination of the X1-X4 indices required comparative analyses of each plot size and each method of land use in a plot (X5-X19). Sokołowski's non-model measure, normalised in the $<0 ; 100>$ range, was used for this purpose. It was used to determine the level of the lack of data coherence [42] based on many attributes. The ultimate measure of coherence is shown in Equation (1).

$$
W_{i}=\left[100-\left(\frac{100}{m} \sum_{j=1}^{m} a_{i} x_{i j}\right)\right]
$$

where: $W_{i}$-measure of coherence, $m-$ number of analysed attributes, $x_{i j}$-attributes of an analysed object, $a_{i}$-weight of an attribute.

The accumulated data were normalised based on Equation (2) and (3) [42]:

$$
\begin{aligned}
\text { for stimulant } x_{i j} & =\frac{x_{i j}-\min \left(x_{i j}\right)}{\max \left(x_{i j}\right)-\min \left(x_{i j}\right)} \\
\text { for destimulant } x_{i j} & =\frac{\max \left(x_{i j}\right)-x_{i j}}{\max \left(x_{i j}\right)-\min \left(x_{i j}\right)}
\end{aligned}
$$

where: stimulant-a variable whose increase implies an increase in the phenomenon under analysis; destimulant-a variable whose increase implies a decrease in the phenomenon under analysis.

In total, 4398 plots situated in 14 villages were analysed. The basic parameters of the data under analysis are shown in Table 1. 
Table 1. Basic parameters of raw data.

\begin{tabular}{|c|c|c|c|c|c|}
\hline Symbol & Coefficient & Measure & Average & Max & Min \\
\hline $\mathrm{X} 1$ & Average absolute change of plot area in the village & $\%$ & 1.4057 & 6.09 & 0 \\
\hline $\mathrm{X} 2$ & Index of the number of plots with a changed area & $\%$ & 65.07 & 100 & 4 \\
\hline $\mathrm{X} 3$ & The number of areas whose size changed & - & 10 & 15 & 6 \\
\hline $\mathrm{X} 4$ & Average absolute change of area size in an object & ha & 1.3128 & 8.1401 & 0.3043 \\
\hline X5 & Change of $\mathrm{R}$ (arable land) area & ha & 7.1045 & 42.8086 & 0.0517 \\
\hline X6 & Change of $€$ (meadows) area & ha & 0.1979 & 1.0165 & 0.0115 \\
\hline $\mathrm{X} 7$ & Change of Ps (pastures) area & ha & 0.9120 & 2.4157 & 0.0018 \\
\hline $\mathrm{X} 8$ & Change of S (orchards) area & ha & 0.8970 & 10.398 & 0.0009 \\
\hline X9 & Change of $\mathrm{N}$ (wasteland) area & ha & 0.0272 & 0.1528 & 0 \\
\hline $\mathrm{X} 10$ & Change of Dr (roads) area & ha & 0.1052 & 0.5926 & 0.0003 \\
\hline $\mathrm{X} 11$ & Change of B (residential) area & ha & 2.4475 & 8.1276 & 0.0243 \\
\hline $\mathrm{X} 12$ & Change of $\mathrm{Ba}$ (industrial) area & ha & 0.1422 & 1.2406 & 0 \\
\hline $\mathrm{X} 13$ & Change of $\mathrm{Bi}$ (other) area & ha & 1.9322 & 6.6488 & 0.6570 \\
\hline $\mathrm{X} 14$ & Change of Bp (built-up industrial) area & ha & 0.2449 & 1.2689 & 0.0007 \\
\hline $\mathrm{X} 15$ & Change of Lz (wooded and bushy) area & ha & 5.0315 & 43.2011 & 0.0002 \\
\hline $\mathrm{X} 16$ & Change of Ls (forest) area & ha & 0.1930 & 0.6653 & 0.0033 \\
\hline $\mathrm{X} 17$ & Change of Wp (flowing waters) area & ha & 0.0130 & 0.0734 & 0.0001 \\
\hline $\mathrm{X} 18$ & Change of $W$ (drainage ditches) area & ha & 0.2879 & 2.0685 & 0.0001 \\
\hline X19 & Change of Ws (ponds) area & ha & 0.1556 & 1.8664 & 0.0810 \\
\hline
\end{tabular}

\section{Results}

The changes in individual plot areas as a result of the cadastral data modernisation ranged from $-60.5 \%$ to $105 \%$. The largest differences were noted in object J-Komorniki (from $-58 \%$ to $105 \%$ ) and L-Kuzocin (from $-60.5 \%$ to $95 \%$ ). The smallest area changes were observed in Dobra Golesze (F) and Golesze (G). Such large changes were not observed in all the plots in the object. A detailed distribution of plot area changes resulting from the modernisation is shown in Figure 4. It shows the plot size change indices for each plot under study, sorted in increasing order. The number of plots was different in each village, which is shown on the $\mathrm{X}$-axis. The $\mathrm{Y}$-axis shows the percentage change of the plot sizes. The longer the line at $0 \%$, the more plots did not change their size as a result of cadastral data modernisation. This applies in particular to Adamów (A), Wolbórz (N), Kaleń (I) and Golesze $(\mathrm{G})$. A rapid change of the line direction indicates that there were few plots in an object whose size did not change. It applies in particular to Kolonia Żywocin (M), Krzykowice (K) and Kuzocin (L).

Average absolute plot area changes for individual objects (villages) range from $0 \%$ to $6 \%$. The largest average absolute changes in plot areas in Kuzocin (L). There is also another characteristic feature of this object-the area of nearly every plot under study (98\%) changed (see Figure 5).

An analysis was also performed of the sizes of specific land use areas, which are part of cadastral data. In general, changes occurred in 15 different land use methods. They were the most frequent in arable land (X5), pastures (X7), land used for transport (X10) and residential areas (X11) (see Table 2). The smallest number of area changes were observed in land under ponds (X19) - this occurred in three objects (A-Adamów, L-Kuzocin and $\mathrm{N}$-Wolbórz). In general, industrial areas (X12) did not usually change, either (see Table 2).

The average change in the area of individual land use in all the objects under study: arable land (X5) - 7.1045 ha, residential areas (X11) — 2.4476 ha, other built-up areas (X13) -3.0056 ha, woody and bushy areas (X15) -7.0441 ha (see Figure 6). The other land use type areas changed by less than 1 ha.

The largest average changes in land use type areas were noted in Janów $(\mathrm{H})-8.1401$ ha, Kaleń (I)—3.4478 ha and in Wolbórz (N) -2.0807 ha. Changes in the other objects did not exceed 2 ha. 


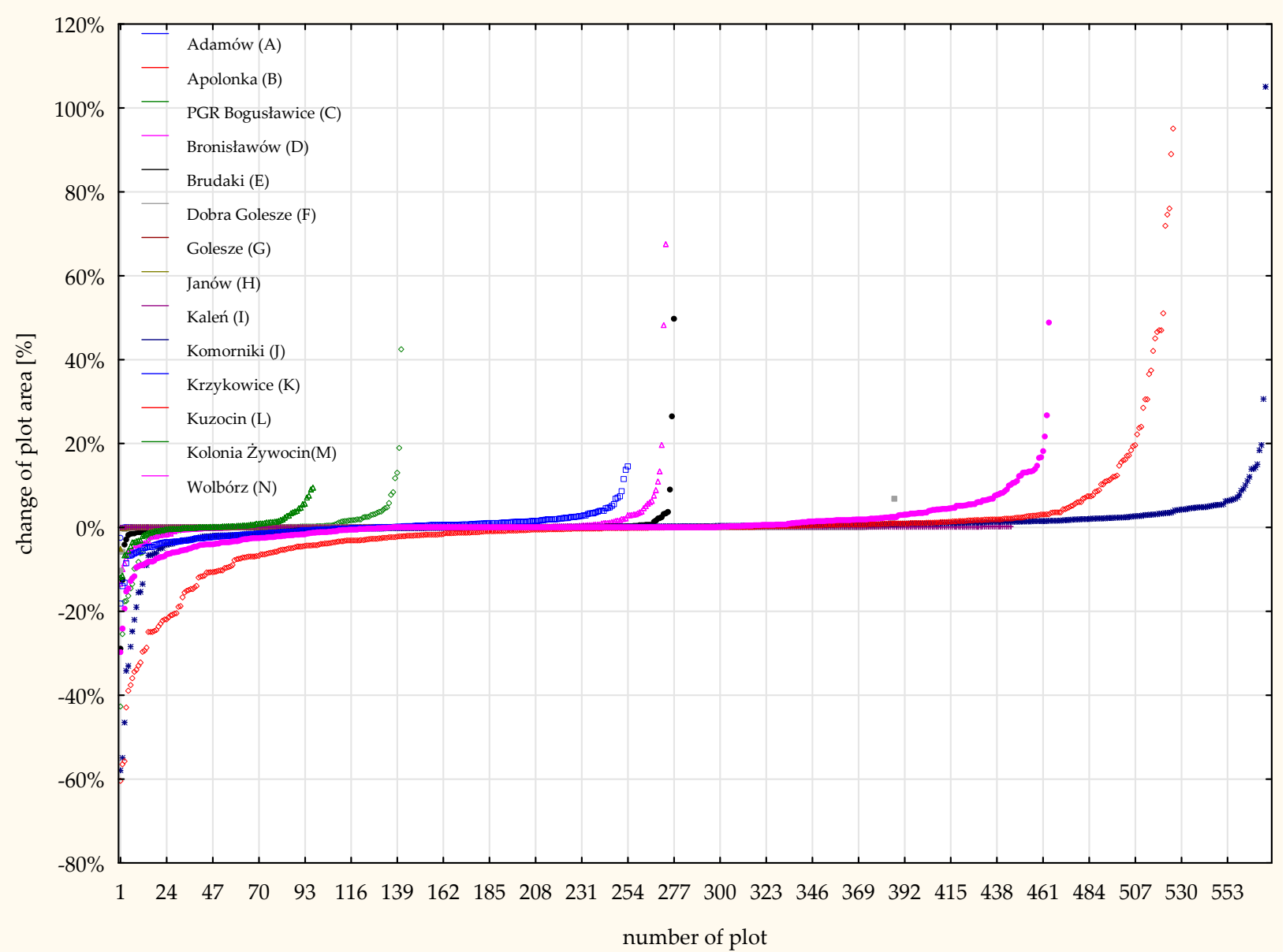

Figure 4. Distribution of plot area changes resulting from the cadastral data modernisation in the area under analysis. Source: own study.

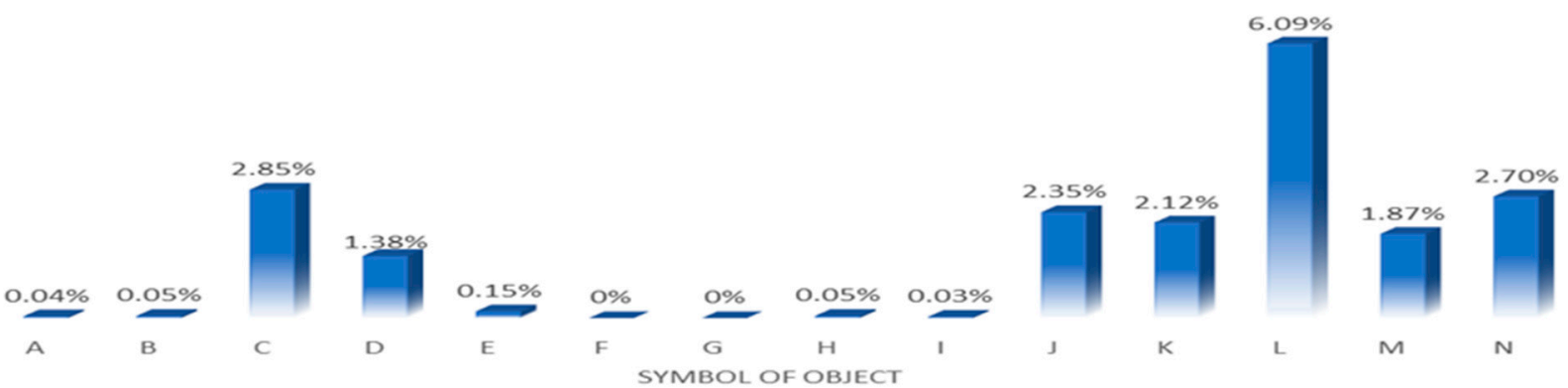

Figure 5. Average absolute change of a plot area. Source: own study. 
Table 2. Absolute changes in land use areas after cadastral data modernisation in all the objects under study.

\begin{tabular}{|c|c|c|c|c|c|c|c|c|c|c|c|c|c|c|c|}
\hline \multirow{2}{*}{$\begin{array}{c}\text { Symbol } \\
\text { Of Land } \\
\text { Use }\end{array}$} & \multicolumn{15}{|c|}{ Of the Object } \\
\hline & $\begin{array}{c}\text { Average } \\
\text { [ha] }\end{array}$ & $\mathbf{A}$ & B & $\mathrm{C}$ & D & $\mathrm{E}$ & $\mathbf{F}$ & G & $\mathbf{H}$ & I & $\mathbf{J}$ & $\mathbf{K}$ & $\mathbf{L}$ & $\mathbf{M}$ & $\mathbf{N}$ \\
\hline X5 & 7.1045 & -4.6759 & -5.7225 & -0.1834 & -6.7744 & -0.0517 & -8.0784 & -3.3683 & -42.8086 & -15.1668 & -1.8591 & -6.8784 & 0.5913 & -2.0091 & 1.2952 \\
\hline X6 & 0.2771 & -0.4355 & - & 0.1034 & - & 0.1193 & -0.0115 & - & - & -0.0115 & -0.1452 & -0.2350 & -1.0165 & -0.1851 & 0.5077 \\
\hline $\mathrm{X} 7$ & 0.9120 & -1.0850 & -0.2134 & -1.0961 & -0.0531 & -0.9241 & -1.8553 & -0.6916 & -1.7861 & -2.4157 & -0.1336 & 0.2144 & -0.7319 & 0.0018 & -1.5659 \\
\hline $\mathrm{x} 8$ & 1.0380 & -0.0009 & - & -0.0090 & -0.0382 & - & -0.5055 & -0.1959 & -0.0658 & -0.2054 & -0.0646 & -0.2740 & -0.1004 & -0.5987 & -10.3980 \\
\hline X9 & 0.0318 & 0 & 0 & -0.1528 & -0.0227 & 0.0026 & 0.0002 & -0.0200 & 0.0770 & - & - & 0.0498 & -0.0272 & -0.0271 & -0.0018 \\
\hline $\mathrm{X} 10$ & 0.1052 & 0.0225 & 0.0182 & -0.0383 & 0.0108 & -0.1744 & -0.0425 & -0.0391 & 0.0003 & 0.0009 & -0.5926 & -0.1069 & -0.1980 & -0.1414 & 0.0866 \\
\hline $\mathrm{X} 11$ & 2.4476 & 4.7144 & -0.2144 & -0.3642 & 3.2603 & 0.0243 & -2.0779 & 4.8576 & 0.5553 & 8.1276 & 2.4572 & 0.6508 & -0.7216 & 2.5371 & 3.7031 \\
\hline $\mathrm{X} 12$ & 0.3982 & 0.0003 & - & 0 & -0.3300 & - & -0.4203 & - & - & - & - & - & - & - & 1.2406 \\
\hline $\mathrm{X} 13$ & 3.0056 & -3.6689 & - & 0.7476 & -2.4897 & - & 4.4131 & -2.2108 & 0.6570 & -4.5445 & - & - & 1.6700 & - & 6.6488 \\
\hline $\mathrm{X} 14$ & 0.4286 & -0.2342 & - & - & -0.1825 & - & -0.1863 & -1.2689 & -0.3071 & - & - & -0.0007 & - & -0.1608 & -1.0883 \\
\hline $\mathrm{X} 15$ & 7.0441 & 5.8951 & 5.7333 & -0.0678 & 6.7540 & 1.1392 & - & - & 43.2011 & - & - & 6.7055 & 0.1685 & 0.7759 & 0.0002 \\
\hline $\mathrm{X} 16$ & 0.2457 & -0.5406 & - & -0.0089 & - & -0.2621 & 0.0756 & 0.0033 & -0.0722 & 0.5527 & - & -0.4237 & -0.0872 & -0.0111 & -0.6653 \\
\hline $\mathrm{X} 17$ & 0.0363 & - & - & 0.0360 & - & - & 0.0001 & - & - & - & - & 0.0196 & -0.0522 & - & -0.0734 \\
\hline $\mathrm{X} 18$ & 0.3101 & 0.0848 & -0.0001 & 1.1712 & - & 0.0413 & -0.1836 & 0.0293 & -0.0106 & -0.0054 & 0.0566 & 0.0465 & -0.3076 & -0.0256 & -2.0685 \\
\hline X19 & 0.7262 & -0.0810 & - & - & - & - & - & - & - & - & - & - & 0.2311 & - & -1.8664 \\
\hline
\end{tabular}




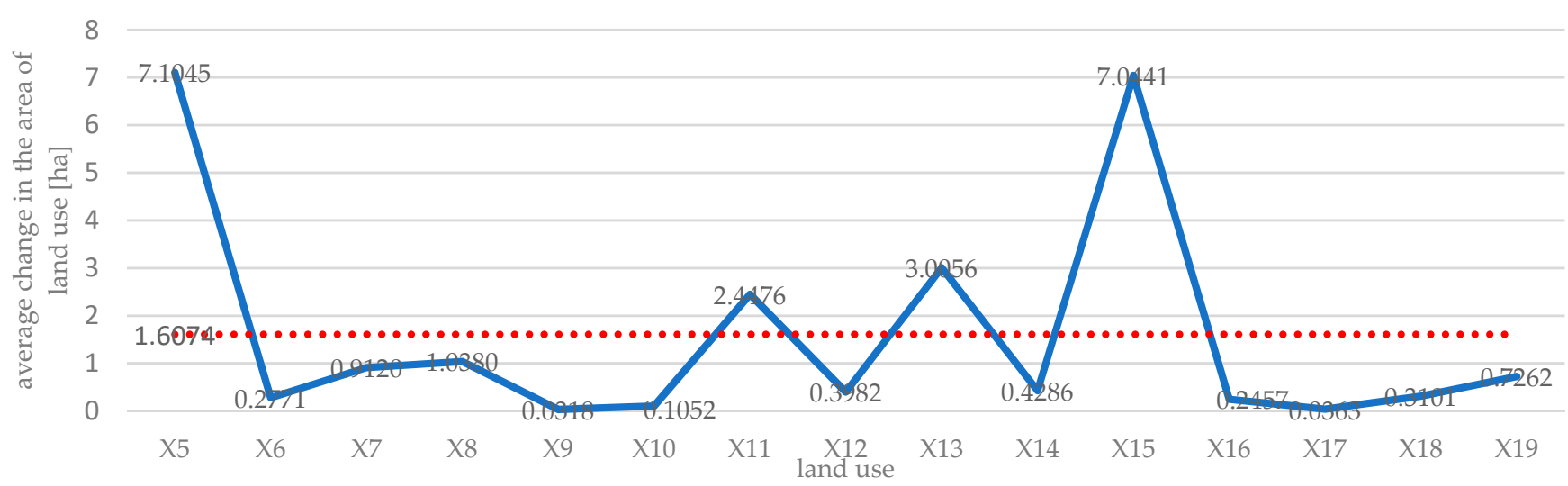

Figure 6. Average change in the area of land use [ha]. Source: own study.

An analysis of changes in land use in individual objects showed that: they are noticeable in arable land (X5) in object A-Adamów, where its area decreased by 4.6759 ha and the size of other built-up areas (X13) decreased by 3.6689 ha. Residential areas (X13) increased in size by 4.7144 ha, and woody and bushy land (X15) by 5.8951 ha. In object B-Apolonka the area of arable land (X5) decreased by $5.7225 \mathrm{ha}$, whereas the area of wooded and bushy land (X15) increased by 5.7333 ha. In object C-PGR Bogusławice the pasture area (X7) decreased by 1.0961 ha and the area of land under drainage ditches (X18) increased by 1.1712 ha. In object D-Bronisławów the area of arable land (X5) and of other built-up land (X13) decreased by 6.7744 ha and 2.489 ha, whereas the area of residential land (X11) and wooded and bushy land (X15) increased by 3.2603 ha and 6.7540 ha. In object E-Brudaki the area of pastures (X7) decreased by 0.9241 ha, whereas the area of wooded and bushy land (X15) increased by 1.1392 ha. In object F-Dobra Golesze the area of arable land (X5) decreased by 8.0784 ha, that of pastures (X7) by 1.8553 ha and residential land (X11) by 2.0779 ha, whereas the area of other built-up land (X13) increased by 4.4131 ha. In object G-Golesze the area of arable land (X5) decreased by 3.3683 ha, the area of other built-up land (X13) by 2.2108 ha and the area of industrial built-up land (X14) by 1.2689 ha, whereas the area of residential land (X11) increased by 4.8576 ha. In object H-Janów the area of arable land (X5) decreased by 42.8086 ha and that of orchards (X8) by 1.7861 ha, whereas the area of wooded and bushy land (X15) increased by 43.2011 ha. In object I-Kalen the area of residential land (X11) increased by $8.1276 \mathrm{ha}$, mainly at the expense of arable land (X5), 15.1668 ha, and other built-up land (X13), 4.5445 ha. In object J-Komorniki the area of built-up land (X11) increased by 2.4572 ha at the expense of arable land (X5), 1.8591 ha, whereas in object K-Krzykowice the area of wooded and bushy land (X15) increased by $6.7055 \mathrm{ha}$, also at the expense of arable land (X5), $8.8784 \mathrm{ha}$.

In object L-Kuzocin the area of other built-up land (X13) increased by 1.6700 ha at the expense of pastures (X7)-1.0165 ha. In object M-Kolonia Żywocin the area of residential land (X11) increased by 2.5371 ha at the expense of arable land (X5)-2.0091 ha. A comparison of changes in the land use from agricultural land to residential land is shown in Figure 7. Data concerning the status of space during two time periods are available owing to the Geoportal [40] project executed by the Head Office of Geodesy and Cartography in Warsaw and it complies with the INSPIRE directive [43]. Its main objective is to share spatial information with citizens, entrepreneurs and public administration.

In the last object, $\mathrm{N}$-Wolbórz, an increase in the area of arable land (X5), residential land (X11), industrial land (X12), other built-up land (X13) and drainage ditches (X18) at the expense of pastures (X7), orchards (X8) and flowing waters was observed (see Table 2). The absolute sizes of the area changes in individual objects and types of land use are listed in Table 3. 


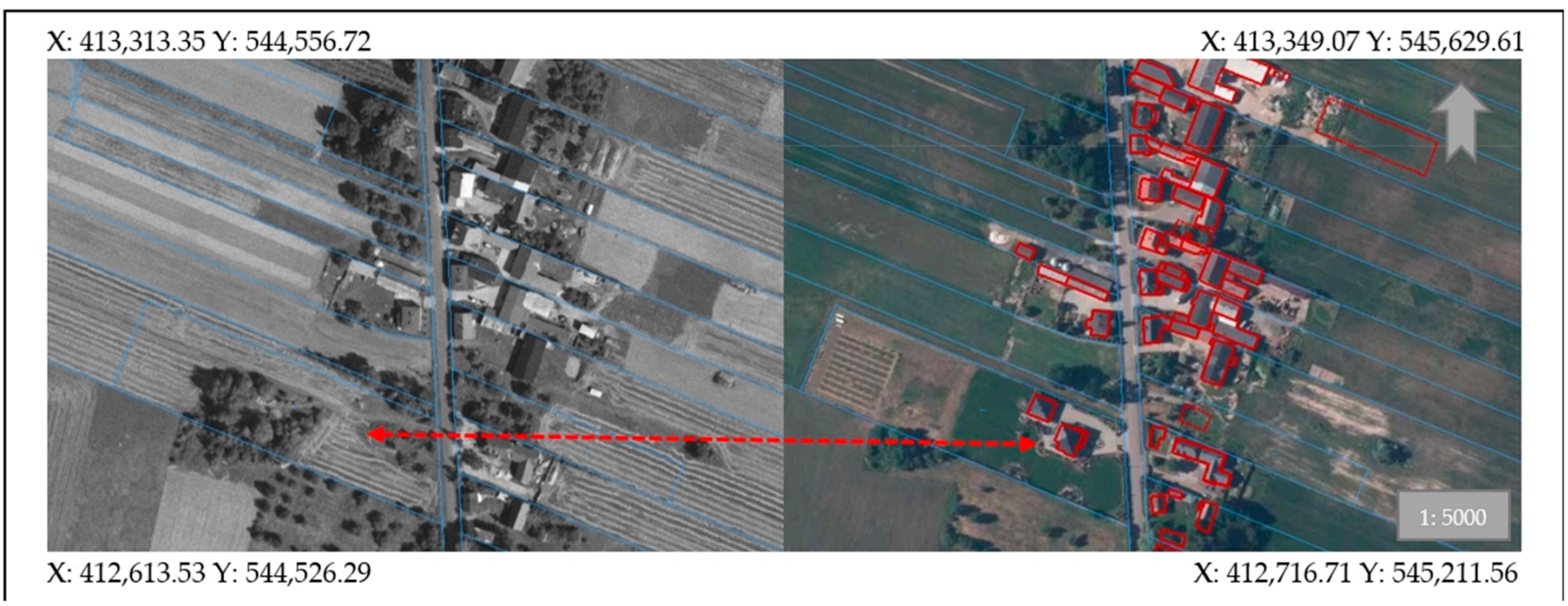

Figure 7. Changes of the land use types over time from agricultural land (2010—left) to residential land (2020—right). X, Y-coordinates of the corners of the image. Source: own study [40].

The arable land area (X5) changed the most often-it took place in 10 objects; this land use type usually changed to residential land (X11) or wooded and bushy land (X15) (see Table 3).

The coherence index $\left(\mathrm{W}_{\mathrm{i}}\right)$ was calculated from Equation (1) with variables X1-X4 for each object under study. The normalisation was performed based on Equation (2) and (3). The highest level of post-modernisation data coherence with primary data was observed in Komorniki (J)—79.64\%, Kuzocin (L)—79.56\% and Adamów (A)—77.43\% (see Figure 8). In Komorniki (J), $97 \%$ of plots changed their area by an average of $2.35 \%$; the area of 7 methods of land use changed by an average of 0.7584 ha. In Kuzocin (L), $98 \%$ of plots changed their area by an average of $6.09 \%$; the area of 13 methods of land use changed by an average of 0.4541 ha. In Adamów (A), only $29 \%$ of plots changed their area by an average of $0.04 \%$; the area of 15 methods of land use changed by an average of 1.5314 ha.

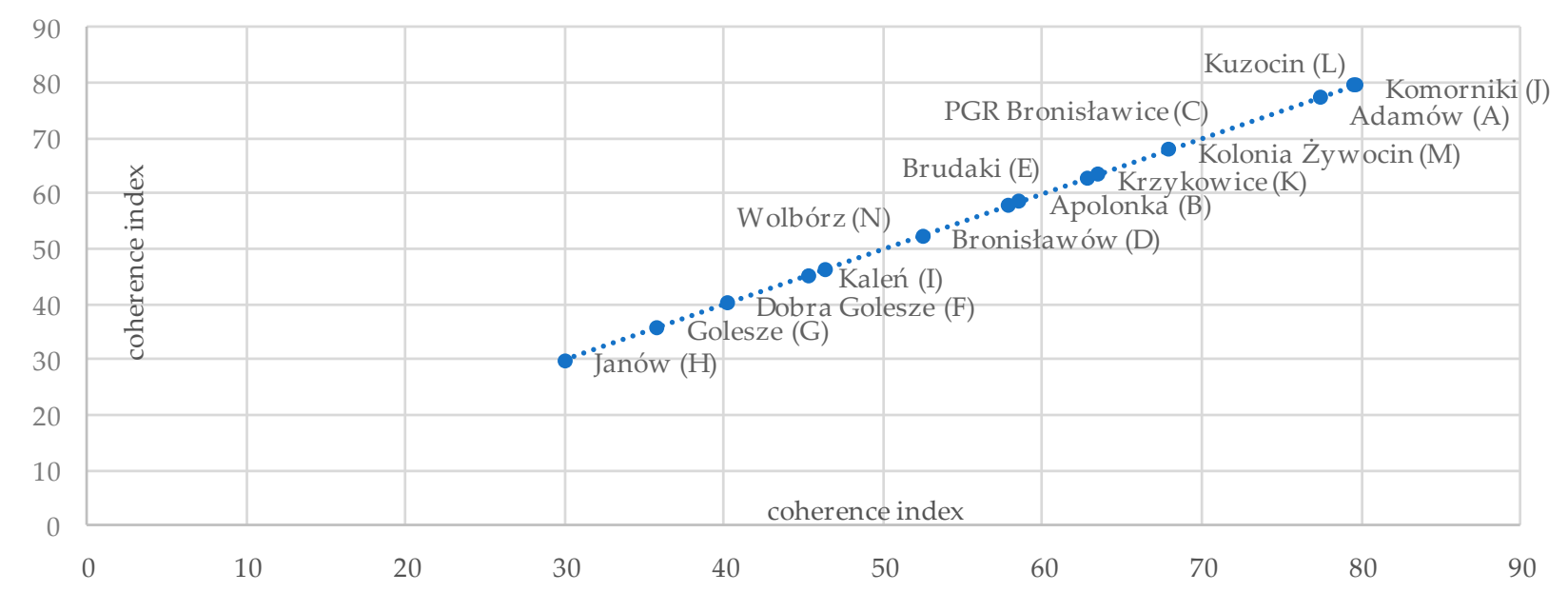

Figure 8. The ranking of objects with respect to the cadastral data coherence with primary data. Source: own study.

The lowest level of coherence was observed in Janów $(\mathrm{H})-29.98 \%$. The area of $65 \%$ of plots there changed, the changes not being large, as the average change was by $0.05 \%$, but the change of the methods of land use was more significant (8.1401 ha on average). Arable land (X5) turned into wooded and bushy land (X15) because of the lack of tillage and allowing natural vegetation to grow. The ranking is shown in Figure 8. 


\section{Discussion}

Land management at the commune level includes many measures, e.g., real estate sale, division, consolidation, lease, expropriation and other ownership transformations, and participation in the construction of technical infrastructure devices [44]. Their success is often determined by the quality and availability of information on real estate [1-4]. The accuracy of information acquired by real estate managing entities from public records has a direct impact on the land management processes [45-47]. Discrepancies between data gathered in the cadaster and the field are caused by various factors. They include (a) ambiguous definitions of individual groups of land use, (b) a multitude of land use types within individual groups, which makes their interpretation difficult, (c) changes of regulations on classification of individual groups, (d) changes of qualification of objects which have to be disclosed in cadastral data, (e) required accuracy of data entries, and (f) failure to report the changes by real estate owners [7,8,14,34-36,48,49]. Lack of data currency is a frequent phenomenon and they have to be modernised to maintain their adequate quality. One should not forget the rapid technological progress [15-20], related to measurement capabilities, which makes data on the plot area and individual methods of land use more accurate. New technologies enable adding another (third) cadastral data dimension [21-25]. Data quality is very important both now, as it affects land management processes, and at the public finance level [46-49] in regard to future development trends. The tax in Poland is calculated based on the area and the method of land use, which is why data modernisation is of particular importance for local governments, which are the tax beneficiaries. This particularly applies to data covering the land for which the tax rate is the highest, i.e., land with buildings of various functions. There is a great difference in the tax rate for buildings of various functions, e.g., the tax on a building used for business activities is 30 times higher than the tax on a residential building [50]. There are situations in which a building was not disclosed in the cadaster or it was disclosed but with incorrect parameters (area, current use). In such cases, the commune loses a considerable portion of the tax income. This phenomenon is confirmed by reporting data for the case study under analysis. The amount of real estate tax revenue in two time periods was compared: before (2011) and after the cadastral data modernisation (2015) [50,51]. The data were acquired from the budget execution report (see Table 3). The tax rates did not increase during the analysed period. The tax revenue differs depending on land use. To put it simply, there is (a) the estate duty (different rates for the land and the building), which applies to land with a building, and agricultural land and buildings used for agricultural production are excluded, (b) land tax, which applies to agricultural land except for land taken for activities other than agriculture and (c) forest tax (it applies to land with trees), which covers forest land classified as forests - except for forests taken for activities other than forestry [28-31].

Table 3. Comparison of the real estate tax revenue before and after cadastral data modernisation.

\begin{tabular}{|c|c|c|}
\hline Year & Description & Budget from Property Tax [PLN] \\
\hline \multirow{4}{*}{ Before modernization cadastral data } & Estate duty & $4,288,817.00$ \\
\hline & Agricultural tax & $817,022.00$ \\
\hline & Forest tax & $65,000.00$ \\
\hline & total & $5,170,839.00$ \\
\hline \multirow[t]{4}{*}{ After modernization cadastral data } & Real estate tax & $4,962,197.00$ \\
\hline & Agricultural tax & $536,087.00$ \\
\hline & Forest tax & $72,043.00$ \\
\hline & & $5,570,327.00$ \\
\hline \multirow[t]{4}{*}{ Difference } & Real estate tax & $673,380.00$ \\
\hline & Agricultural tax & $-280,935.00$ \\
\hline & Forest tax & 7043.00 \\
\hline & & $399,488.00$ \\
\hline
\end{tabular}


The table on the real estate tax revenue reveals some regularities. The revenue before modernisation was higher by PLN 280,935 than after modernisation. This is a consequence of the process. The land previously classified as agricultural land changed according to the new, actual method of use and now corresponds to the new status. As a result of the change in land use, the revenue on estate duty increased by PLN 673,380. In general, the real estate tax revenue in the commune increased by nearly $10 \%$ without any outside interference of the commune authorities, e.g., change of tax rates for different methods of land use. Considering the average cost of cadastral data modernisation, the procedure will pay for itself within just one year. An increase in the commune budget revenue is a consequence of the increase of the tax base, i.e., the area of land and buildings, which were not entered in the register earlier $[50,51]$. The analyses performed by Noszczyk and Hernik $[46,47]$, produced similar findings. They demonstrated a considerable increase in tax income following the data modernisation.

Changes can be rapid in some land use types, without the landowners or holders participating in them. This mainly concerns the range of flowing waters, wooded and bushy land or dirt roads. It is mainly a consequence of the fact that flowing waters (rivers, brooks, springs, canals, lakes out of or into which streams flow, artificial water reservoirs out of (or into) which streams flow) can change their range depending on the number and amount of rainfall. According to the definition, the contour of land under flowing surface waters is outlined by the line of shores of natural flows, lakes and other natural water bodies and the external edges of canals or artificial water reservoirs situated on flowing waters [28]. The shoreline of a natural water body is the shore edge (when the line is distinct), the line of permanent grass (when the line is fuzzy) or the line determined as the average water level for at least the past 10 years [52]. Thus defined, the border between water and land undergoes frequent deformations. Figure 9 shows changes in the borders of a water flow (Wp) after cadastral data modernisation.

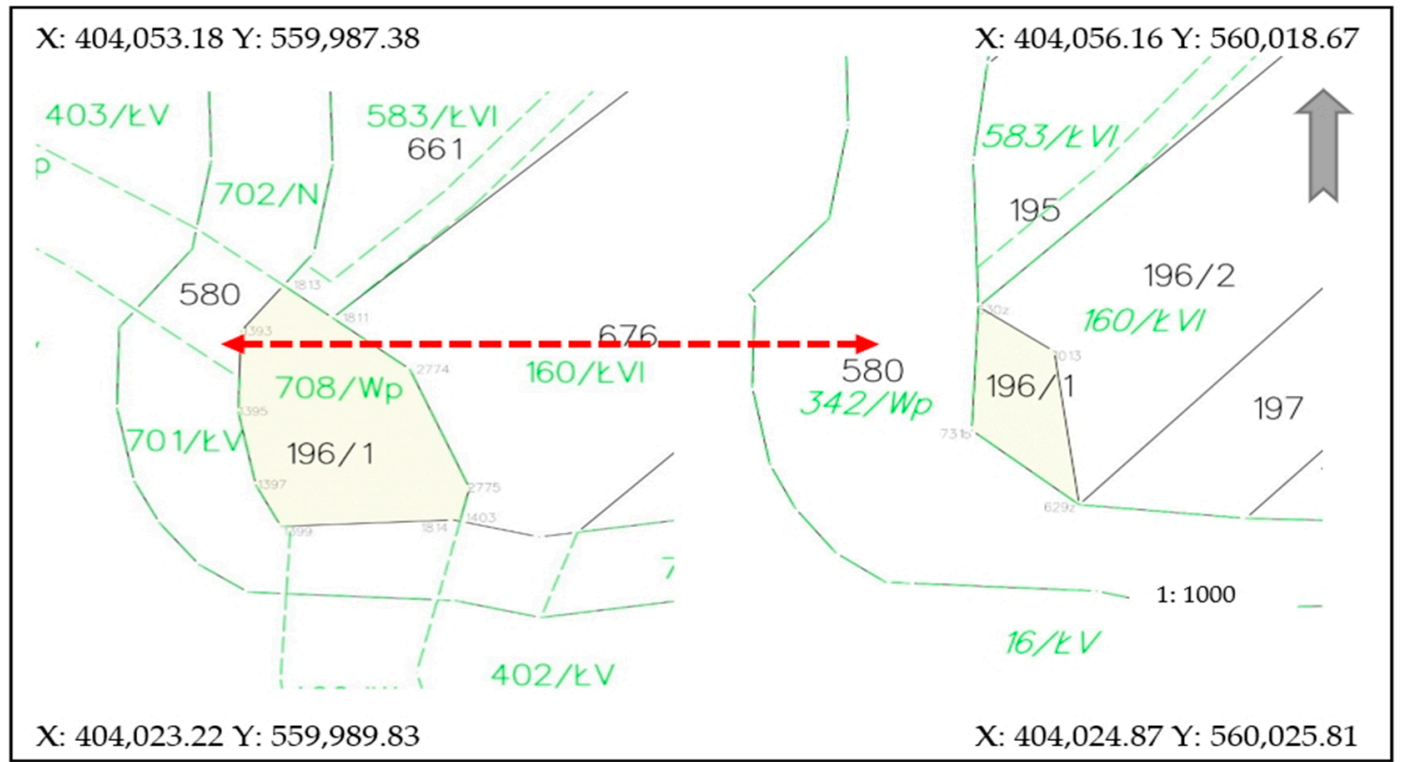

Figure 9. Change in water flow borders after cadastral data modernisation—state before and after modernisation. X, Y-coordinates of the corners of image. Source: own study.

Changes in the watercourse borders affect the spatial range of exercising the ownership right. If the river border is different in a document than in the cadaster, the individual owner has a plot of a smaller or larger size. In consequence, an incorrect area registered in the cadaster and inconsistent with the situation on the ground (the river changes its course naturally) has a cascading impact on the formation of further irregularities, e.g., insurance, spatial planning, tax-related, sale-related, fiscal documents, payments and EU subsidies. 
Therefore, up-to-date cadastral data not only secure individual owners' rights, but also those of third parties (potential buyers, insurance companies, etc.).

Borders of other land use areas may change because the landowner failed to take appropriate actions. For example, a piece of land in the immediate neighborhood of a forest is transformed quickly by the unlimited growth of vegetation. In this case, the passage of time made the newly formed forests denser and taller. Starting an investment project will result in serious inconveniences. They are a consequence of the incorrect size of the method of use. Restoring the land under analysis to a method of use other than a forest implies removing the trees. An official issuing a permit for carrying out the investment or for cutting down the trees [53] should evaluate the situation in the field, as a decision based on obsolete cadastral data would be one based on wrong premises. Figure 10 shows an area which was used for agriculture in 2010 (acr. R) and it was wooded and bushy land in 2020 (acr. Lz).

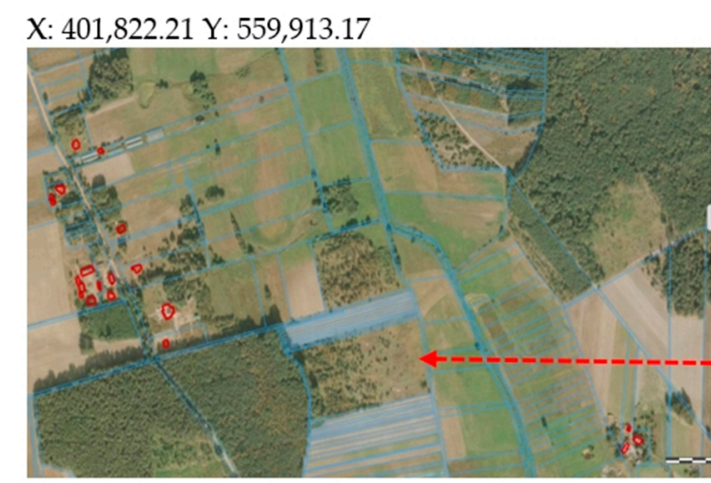

X: 401,808.98 Y: 558635.22

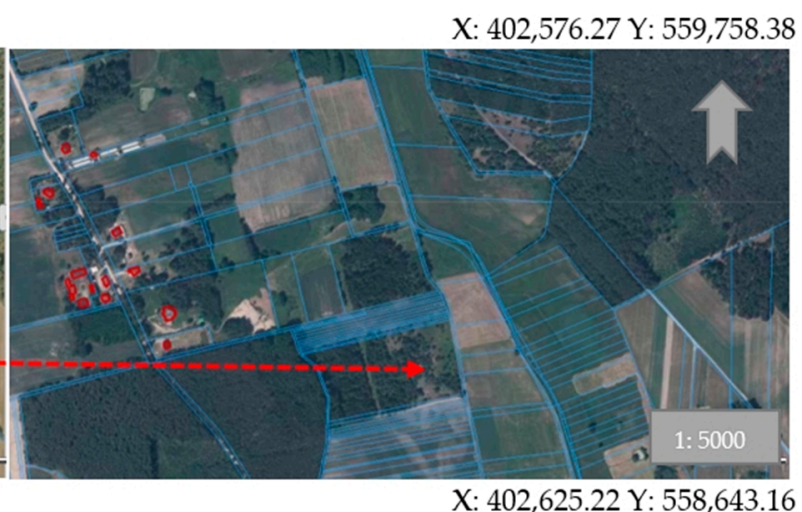

$X: 402,625.22$ Y: $558,643.16$

Figure 10. Natural succession resulting from the plot owner's failure to take relevant actions. Comparison of the state in 2010 (left) and in 2020 (right). X, Y-coordinates of the corners of the depicted image. Source: own study [40].

This case study covered rural areas. Issues created by a lack of coherence of cadastral data with the situation in the field in urban or suburban areas are wider and may be more difficult. They mainly arise from the fact that there are many objects of infrastructure of high value at such locations (e.g., bridges, flyovers, electric poles, etc.) or a high value of the land itself. Decisions taken in such circumstances should be based on reliable and accurate documentation, preferably expanded by the third dimension [21-25,54]. We live in a spatial and multidimensional world and reflecting the real situation in the cadastral system gives the stakeholders a larger information resource, which results in making executive decisions without detriment to the society or the land, objects and buildings situated in a close and more distant neighborhood. Therefore, transition to the next level of cadaster development has to be supported with data reflecting the actual situation in the field.

\section{Conclusions}

Local governments at the commune level have a wide range of tasks to perform. They include economic goals, ownership transformations and participation in the construction of technical infrastructure devices as well as the acquisition of funds to perform these tasks. Cadastral data often provide grounds for many spatial decisions. If they are incoherent with the situation on the ground, it may lead to wrong conclusions. The analysis performed for 14 villages showed that the coherence of the field data and cadastral data varies. The differences range from approx. $30 \%$ to $80 \%$. It shows that modernisations should be carried out more frequently than provided for in guidelines and legal regulations. This applies particularly to areas where the urban areas are expanding rapidly. 
Author Contributions: Conceptualization, K.K.-B.; methodology, K.K.-B.; software, K.K.-B.; validation, K.K.-B.; formal analysis, K.K.-B., H.F.; investigation, K.K.-B.; resources, H.F.; data curation, K.K.-B.; writing—original draft preparation, K.K.-B.; writing-review and editing, K.K.-B.; visualization, K.K.-B., H.F.; supervision, K.K.-B.; project administration, K.K.-B.; funding acquisition, K.K.-B. All authors have read and agreed to the published version of the manuscript.

Funding: This research received no external funding.

Data Availability Statement: Publicly available datasets were analyzed in this study. This data can be found here: https://bdl.stat.gov.pl/BDL/dane/teryt/jednostka, http:/ / www.wolborz.4bip.pl, www.geoportal.gov.pl, https:/ /apd.uwm.edu.pl. The data resulting from the analyzes can be found in the article.

Conflicts of Interest: The authors declare no conflict of interest.

\section{References}

1. Paulsson, J.; Paasch, J.M. The land administration domain model—A literature survey. Land Use Policy 2015, 49, 546-551. [CrossRef]

2. Oukes, P.; van Andel, M.; Folmer, E.; Bennett, R.; Lemmen, C. Domain-driven design applied to land administration system development: Lessons from the Netherlands. Land Use Policy 2021, 104, 105379. [CrossRef]

3. Aien, A.; Kalantari, M.; Rajabifard, A.; Williamson, I.; Wallace, J. Towards integration of 3D legal and physical objects in cadastral data models. Land Use Policy 2013, 35, 140-154. [CrossRef]

4. Van Oosterom, P.; Lemmen, C. Spatial data management on a very large cadastral database. Comput. Environ. Urban Syst. 2001, 25, 509-528. [CrossRef]

5. Roić, M.; Križanović, J.; Pivac, D. An approach to resolve inconsistencies of data in the cadastre. Land 2021, 10, 70. [CrossRef]

6. Stauldler, D. Let's talk about (legal) reliability of the cadastre. In Proceedings of the Report of Joint Conference PCC with EuroGe-ographics-CLRKEN, Vienna, Austria, 20-21 November 2018; pp. 1-29.

7. Cienciała, A.; Sobolewska-Mikulska, K.; Sobura, S. Credibility of the cadastral data on land use and the methodology for their verification and update. Land Use Policy 2021, 102, 105204. [CrossRef]

8. Kocur-Bera, K. Data compatibility between the Land and Building Cadaster (LBC) and the Land Parcel Identification System (LPIS) in the context of area-based payments: A case study in the Polish Region of Warmia and Mazury. Land Use Policy 2019, 80, 370-379. [CrossRef]

9. van Oort, P.A. Spatial Data Quality: From Description to Application; Wageningen Universiteit: Wageningen, The Netherland, 2006.

10. Li, D.; Zhang, J.; Wu, H. Spatial data quality and beyond. Int. J. Geogr. Inf. Sci. 2012, 26, 2277-2290. [CrossRef]

11. Elements of Spatial Data Quality; Guptill, C.; Morrison, J.L. (Eds.) Elsevier: Washington, DC, USA, 2013.

12. Devillers, R.; Stein, A.; Bédard, Y.; Chrisman, N.; Fisher, P.; Shi, W. Thirty years of research on spatial data quality: Achievements, failures, and opportunities. Trans. GIS 2010, 14, 387-400. [CrossRef]

13. Ali, Z.; Tuladhar, A.; Zevenbergen, J. An integrated approach for updating cadastral maps in Pakistan using satellite remote sensing data. Int. J. Appl. Earth Obs. Geoinf. 2012, 18, 386-398. [CrossRef]

14. Hanus, P.; Peska-Siwik, A.; Szewczyk, R. Spatial analysis of the accuracy of the cadastral parcel boundaries. Comput. Electron. Agric. 2018, 144, 9-15. [CrossRef]

15. Stöcker, C.; Nex, F.; Koeva, M.; Gerke, M. High-quality UAV-based orthophotos for cadastral mapping: Guidance for optimal flight configurations. Remote Sens. 2020, 12, 3625. [CrossRef]

16. Puniach, E.; Bieda, A.; Ćwiąkała, P.; Kwartnik-Pruc, A.; Parzych, P. Use of Unmanned Aerial Vehicles (UAVs) for updating farmland cadastral data in areas subject to landslides. ISPRS Int. J. Geo-Inf. 2018, 7, 331. [CrossRef]

17. Crommelinck, S.; Bennett, R.; Gerke, M.; Nex, F.; Yang, M.Y.; Vosselman, G. Review of automatic feature extraction from high-resolution optical sensor data for UAV-based cadastral mapping. Remote Sens. 2016, 8, 689. [CrossRef]

18. Crommelinck, S.; Höfle, B.; Koeva, M.N.; Yang, M.Y.; Vosselman, G. Interactive cadastral boundary delineation from Uav data. ISPRS Ann. Photogramm. Remote Sens. Spat. Inf. Sci. 2018, IV-2, 81-88. [CrossRef]

19. Wierzbicki, D.; Matuk, O.; Bielecka, E. Polish cadastre modernization with remotely extracted buildings from high-resolution aerial orthoimagery and airborne LiDAR. Remote Sens. 2021, 13, 611. [CrossRef]

20. Asghari, A.; Kalantari, M.; Rajabifard, A. A structured framework for 3D cadastral data validation-A case study for Victoria, Australia. Land Use Policy 2020, 98, 104359. [CrossRef]

21. Larsson, K.; Paasch, J.M.; Paulsson, J. Conversion of 2D Analogue Cadastral Boundary Plans into 3D Digital Information: Problems and Challenges Illustrated by a Swedish Case. In 6th International FIG 3D Cadastre Workshop [Internet]. 2018, pp. 75-94. Available online: http:/ / urn.kb.se/resolve?urn=urn:nbn:se:hig:diva-28327 (accessed on 24 March 2021).

22. Larsson, K.; Paasch, J.M.; Paulsson, J. Representation of 3D cadastral boundaries-From analogue to digital. Land Use Policy 2020, 98, 104178. [CrossRef]

23. Kitsakis, D.; Paasch, J.M.; Paulsson, J.; Navratil, G.; Vučić, N.; Karabin, M.; Flávia, A.; El-Mekawy, M. 3D Real Property Legal Concepts and Cadastre: A Comparative Study of Selected Countries to Propose a Way Forward. In Proceedings of the 5th International Workshop on 3D Cadatres, Athens, Greece, 18-20 October 2016; pp. 1-24. 
24. Seipel, S.; Andrée, M.; Larsson, K.; Paasch, J.M.; Paulsson, J. Visualization of 3D property data and assessment of the impact of rendering attributes. J. Geovisualization Spat. Anal. 2020, 4, 1-17. [CrossRef]

25. van Oosterom, P. Best Practices 3D Cadastres; International Federation of Surveyors (FIG): Delft, The Netherlands, 2020 ; p. 258.

26. UNECE. Guidelines on Real Property Units and Identifiers; Economic Commission for Europe: Geneva, Switzerland, 2004.

27. UNECE. Survey on Land Administration System. New York and Geneva. 2014. Available online: http://www.Unece.org (accessed on 15 February 2021).

28. Regulation of the Minister of Regional Development and Construction on 29 March 2001 on the Registration of Land and Buildings. Available online: http:/ / www.isap.gov.pl (accessed on 3 March 2020).

29. Act of 12 January 1991 o podatkach i opłatach lokalnych (DzU. Nr 9 poz. 31). Available online: http:/ / www.Isap.gov.pl (accessed on 14 January 2021).

30. Act of 15 November 1984 agricultural tax (Dz.U. 52, poz. 268). Available online: http:/ /www.isap.gov.pl (accessed on 11 January 2021).

31. Act of 30 October 2002 forest tax (Dz. U. z 2019 r. poz. 888). Available online: http:/ / www.isap.gov.pl (accessed on 10 January 2021).

32. Polsko-Hiszpańska Izba Gospodarcza. Available online: https:/ /www.phig.pl/pl/porady/107/ (accessed on 10 January 2021).

33. Legal Services. Available online: https://legaltime.by/pl/llc-taxation-belarus/ (accessed on 10 January 2021).

34. Kocur-Bera, K.; Stachelek, M. Geo-analysis of compatibility determinants for data in the land and property register (LPR). Geosciences 2019, 9, 303. [CrossRef]

35. Geodetic and Cartographic Law of 17 May 1989 (Journal of Laws 30, item 163). Available online: http://www.isap.gov.pl (accessed on 14 January 2021).

36. Act of 17 June 1966 r. on Enforcement Proceedings in Administration (Dz.U 24, poz. 151). Available online: http:/ /www.isap.gov. $\mathrm{pl}$ (accessed on 14 January 2021).

37. Statistical Data. Available online: http:/ /www.stat.gov.pl (accessed on 16 February 2021).

38. GOOGLE MAPS. Available online: http:/ / www.google.maps.pl (accessed on 15 January 2021).

39. GEOPORTAL. Available online: www.geoportal.gov.pl (accessed on 15 February 2021).

40. Fraszczak, H. Aktualizacja Operatu Modernizacji Ewidencji Gruntów i Budynków na Przykładzie Gminy Wolbórz. Praca inżynierska; UWM Olsztyn: Olsztyn, Poland, 2020; p. 47, In Polish.

41. Sokołowski, A. Analizy Wielowymiarowe; StatSoft Polska: Kraków, Poland, 2014; p. 65.

42. Directive 2007/2/EC of the European Parliament and of the Council of 14 March 2007 Establishing an Infrastructure for Spatial Information in the European Community (INSPIRE). Available online: http://data.europa.eu/eli/dir/2007/2/oj (accessed on 14 January 2021).

43. Act of 21 August 1997 on real estate management (Journal of Laws 115, item 741). Available online: http:/ /www.isap.gov.pl (accessed on 4 November 2020).

44. Samojłowicz, Ł. Ewidencja Gruntów i Budynków w Podatku od Nieruchomości. Rozprawa Doktorska; Uni-wersytet Śląski: Katowice, Poland, 2019; p. 224, In Polish.

45. Noszczyk, T.; Hernik, J. Modernization of the land and property register. Acta Sci. Pol. Form. Circumiectus 2016, 15, 3-17. [CrossRef]

46. Noszczyk, T.; Hernik, J. Understanding the cadastre in rural areas in Poland after the socio-political transformation. J. Spat. Sci. 2017, 64, 73-95. [CrossRef]

47. Mourafetis, G.; Apostolopoulos, K.; Potsiou, C.; Ioannidis, C. Enhancing cadastral surveys by facilitating the participation of owners. Surv. Rev. 2015, 47, 316-324. [CrossRef]

48. Local Low 2011. Available online: https://www.wolborz.4bip.pl/upload/201201171309509rbriz2v6ynh.pdf (accessed on 24 March 2021).

49. Sprawozdanie Burmistrza Wolborza z wykonania budżetu Gminy Wolbórz na dzień 31 grudnia 2009. Available online: http: / /www.wolborz.4bip.pl (accessed on 25 January 2021).

50. The Act of 20 July 2017 Law of water (item 1566). Available online: http:/ / www.isap.gov.pl (accessed on 4 February 2021).

51. Act of 16 April 2004 on Nature Protection. Available online: http:/ / www.isap.gov.pl (accessed on 24 March 2021).

52. Paasch, J.M.; Paulsson, J.; Navratil, G.; Vučić, N.; Kitsakis, D.; Erba, D.; Karabin, M.; El-Mekawy, M. Building a modern cadastre: Legal issues in describing real property in 3D. Géod. Vestnik 2016, 60, 256-268. [CrossRef]

53. Karabin, M.; Kitsakis, D.; Koeva, M.; Navratil, G.; Paasch, J.M.; Paulsson, J.; Vučić, N.; Janečka, K.; Lisec, A. Layer approach to ownership in 3D cadastre in the case of underground tunnels. Land Use Policy 2020, 98, 104464. [CrossRef]

54. Paulsson, J. Reasons for introducing 3D property in a legal system-Illustrated by the Swedish case. Land Use Policy 2013, 33, 195-203. [CrossRef] 